\title{
Which factors are related to Finnish home care workers' job satisfaction, stress, psychological distress and perceived quality of care? - a mixed method study
}

\author{
Salla Ruotsalainen ${ }^{1 *}$, Sami Jantunen ${ }^{2}$ and Timo Sinervo ${ }^{1}$
}

\begin{abstract}
Background: The desire to increase the role of home care in Finland has created problems in home care work. Working conditions have deteriorated, the quality of care experienced is low, and staff members suffer from time pressure and stress, amongst other things. The aim of this article is to explore the challenges, stressors, teamwork and management factors that are associated with home care staff members' well-being, job satisfaction and experienced care quality, and further, how staff members experience their work.

Methods: A survey was sent to home care workers in two case organizations that participated in the study. In addition, semi-structured theme interviews with home care workers were conducted. The data from the survey was analysed using analysis of covariance, and interview data was analysed using the Grounded Theory-based method from Gioia et al.

Results: Respondents of the survey and the interview participants were mainly female practical nurses. The results from the survey showed, for example, that time pressure was associated with higher stress and psychological distress, and interruptions were associated with lower job satisfaction and higher stress. In addition, variables related to teamwork, such as participative safety, were shown to explain the variation in quality of care. The analysis of the interview data further brought up dissatisfaction with management practices, which seems to have led to a decrease in job satisfaction. Exhaustion and strain were present among staff members, which originated from an insufficient number of carers.

Conclusions: Current working conditions and work practices in Finnish home care are experienced stressful. The results from this study indicate that having more autonomy at work was associated with job satisfaction, according to both analyses. Team climate and idea implementation were related to quality of care. Therefore, increasing selforganizing team practices might be a possible development method for improving working conditions and staff members' well-being. Implementing self-organizing team practices could possibly also attract employees to work in home care and prevent turnover.
\end{abstract}

Keywords: Home care, Self-organization, Job satisfaction, Quality of care, Mixed methods

\footnotetext{
* Correspondence: salla.ruotsalainen@thl.fi

${ }^{1}$ Finnish Institute for Health and Welfare, P.O. Box 30, 00271 Helsinki, Finland

Full list of author information is available at the end of the article
}

C C The Author(s). 2020 Open Access This article is licensed under a Creative Commons Attribution 4.0 International License, which permits use, sharing, adaptation, distribution and reproduction in any medium or format, as long as you give appropriate credit to the original author(s) and the source, provide a link to the Creative Commons licence, and indicate if changes were made. The images or other third party material in this article are included in the article's Creative Commons licence, unless indicated otherwise in a credit line to the material. If material is not included in the article's Creative Commons licence and your intended use is not permitted by statutory regulation or exceeds the permitted use, you will need to obtain permission directly from the copyright holder. To view a copy of this licence, visit http://creativecommons.org/licenses/by/4.0/. The Creative Commons Public Domain Dedication waiver (http://creativecommons.org/publicdomain/zero/1.0/) applies to the data made available in this article, unless otherwise stated in a credit line to the data. 


\section{Background}

In recent years, a service structure change has altered the care for older people in Finland. This structural change aimed to decrease the proportion of institutionalised care and significantly increase the proportion of home care provided for older people [1]. A similar trend in the care for older people has been evident elsewhere in Europe, since many countries have prioritised home care in their policies [2]. The objective of moving from institutional care towards more home-based care has been largely achieved in Finland, since institutional care beds (e.g. nursing homes and health centre inpatient wards) have been replaced with lighter solutions, like assisted living facilities and home care [3]. Furthermore, much emphasis has been placed on the development of home care through government key projects related to home care and informal care [4].

The desire to increase the role of home care has created new problems. The staffing of home care has not kept up with increases in home care clients [5]. Visits per day have increased throughout the 2000s, as has the complexity of home care clients' problems. For instance, home care clients had more contacts with health care services compared to those older people living in assisted living facilities or other long-term care facilities [3]. Recent studies conducted among employees in the care for older people in Finland have indicated that working conditions in home care have deteriorated; home care workers experienced more time pressure and stress [6] compared to their counterparts in institutionalised care. In another Finnish study, the major problems in home care were time pressure, role conflict, working alone, interruptions, poor team climate and low organizational justice [7]. These earlier studies suggest that time pressure and other stressors, unjust management and problems in teamwork in particular might be the reasons for poorer well-being and dissatisfaction among Finnish home care workers. Interruptions at work and working alone have also been noted to burden the health care field [8] and home care [9] in other countries. Working alone was experienced stressful since work in home care is very independent and there might not be support available when needed [9].

Perhaps the most well-known theoretical model relating to the work environment and to employee wellbeing is the Job Strain Model, which is based on the idea that staff members with lower autonomy and higher demands at work have more health problems, or higher strain $[10,11]$. Autonomy at work is also related to several positive outcomes, such as job satisfaction [12]. A second theoretical model is the Team Climate Model [13], which focuses on team characteristics. These characteristics are shown to be associated with team innovativeness [13] but also with several well-being issues such as burnout or emotional exhaustion $[14,15]$ and job satisfaction [16]. King et al. showed that a better climate for innovation in health care facilities reduced the negative effects of job demands [17]. The third model is the Organizational Justice Model. Different studies have shown that low organizational justice predicts low job satisfaction, higher stress, psychological stress, negative health effects [18], retirement intentions [19], sickness absence and several other negative outcomes, among others $[15,20,21]$. Furthermore, other studies conducted among care workers have shown that problems with teamwork and low supervisorial justice, for example, were associated with lower job satisfaction [12].

Not only well-being of employees but also the quality of care has decreased in Finnish services for older people, and especially in home care. In a Finnish study home care workers gave a lower grade for quality of care provided at their work unit than in other care facilities [22].

Unlike with employee well-being, there is far less evidence linking job characteristics, stressors, management or teamwork with quality of care. Previous studies conducted in the Finnish older people care context have used both objective (clinical quality outcomes, such as inadequate use of medication, pressure ulcers, use of restraints) and subjective outcomes (such as school grade for quality of care provided in the work unit) to measure care quality $[22,23]$. Earlier studies have indicated that autonomy and job demands are strongly related to quality of care (drug use, pressure ulcers and restraint practices [23]) as well as quality of life [24], which is in line with Karasek model hypotheses. Results from the widely studied Magnet Hospital model showed that those hospitals that had adapted the Magnet principles and had a low organization, high decision-making authority in work units [25] as well as high autonomy [26] among nurses also rated the quality of care higher. Moreover, more supportive work environments were shown to have an impact on care quality [27, 28]. There is also evidence that team climate $[29,30]$ and organizational justice [15] are related to quality of care in primary care.

There is growing evidence that team autonomy or at least a high level of decision authority by the team is related to better outcomes of care on personnel (better job satisfaction, low stress) and on clients (better quality of care). The Magnet Hospital studies give support to this as well as the previously mentioned studies on team climate. The Dutch organization Buurtzorg, which provides home care services, has gained publicity with its promise of increased effectiveness and client and employee satisfaction [31], but these benefits have not largely been confirmed with scientific studies. In the Buurtzorg model of home care teams, there are no supervisors and teams can organize their work autonomously [31]. 
Initiating self-organizing teamwork practices has also shown some promising results elsewhere: A study by Maurits, et al. [32] showed that working in home care in a more self-organizing way was associated with higher job satisfaction. Moreover, in community mental health care, staff members were very satisfied with the increased independence and being able to influence their work more when self-organizing teamwork practices were initiated [33]. Increasing autonomy of teams has also shown to be associated with job satisfaction in other work sectors [34].

There is evidence that all the major models explaining staff members' well-being have an effect on home care workers' well-being as well as quality of care. However, there is not enough evidence of how these different models relate to each other, and which of these factors are most important.

\section{Context of the research}

Home care in Finland refers to a combination of home help services and home nursing. Home help services include assistance with activities such as housing, personal care and other functions related to daily living specified in the Social Welfare Act [35]. Home nursing comprises health and medical care that is provided according to a treatment and care plan, or on a temporary basis, either at the patient's home or in another place of residence [36]. Even if home care also includes home help services, it has become more medical and care-focused during the past years [37] and therefore other needs of the clients, such as housekeeping, have been disregarded. In addition to home help and home nursing, there are support services such as meals on wheels and cleaning services, and these very often need to be paid for out-ofpocket. In this study, from now on, we will use the term home care, since the case organizations in which this study was conducted provide home care that includes both home help services and home nursing.

Home care personnel in Finland mainly comprise practical nurses who have a three-year vocational qualification in social and health care [38]. Their main role is to provide daily care, but especially in home care their role can be broader and they can deliver medication, for instance. The role of a practical nurse is described in more detail elsewhere [19]. By approximately $12 \%$, registered nurses comprise a significantly lower proportion of home care staff [39].

Finland has publicly-funded health and social care services where only a small proportion is produced by private service providers, except in assisted living, where more than half are private service providers (for-profit and not-for-profit). Municipalities are in charge of organizing health and social care services and mainly produce the services. The size of the municipalities can vary from a small rural town of 1000 inhabitants to a metropolitan area with approximately 500,000. In home care, the proportion of privately-produced care that municipalities purchase is only $0.4 \%$ of all home care $[40,41]$.

\section{Methods}

\section{Aim and research questions}

This study is a part of a larger project coaching home care teams towards self-organizing team practices. The aim of this article is to explore challenges, stressors, teamwork and management factors associated with home care workers' well-being, job satisfaction and experienced care quality. Due to the scarcity of previous studies exploring home care workers' well-being, job satisfaction and care quality, we wanted to include several predictors from the previously tested theories that have been shown to have an association with the outcome variables included in the present study. Further, we aimed to identify possible development needs of the work practices. The research questions for the study are:

1. Which teamwork factors, stressors and management related factors are associated with Finnish home care workers'
a) job satisfaction
b) stress
c) psychological distress
d) self-rated quality of care?

2. How do Finnish home care workers perceive their work?

\section{Study design and sample}

In this cross-sectional study we used a mixed methods approach. We chose this approach for complementary purposes, in other words the two methods complemented each other [42]. The data for both quantitative and qualitative analysis was gathered in 2018 before interventions aiming to increase selforganizing work practices in the case organizations took place. A job satisfaction survey and semistructured interviews for home care personnel were the two data sources for the present study and they are described in more detail later in the article. The survey and interviews were used as a preliminary benchmarking of well-being and for mapping the development needs among home care workers. 


\section{Study setting}

The case organizations for the study were from two different locations in Finland. One case organization is responsible for providing home care in a large city in Southern Finland. However, only four districts of the organization were involved in the development project, including 22 teams. Another case organization comprised three home care teams from a smaller town, including more rural parts. Both case organizations are publicly funded and produce health and social care services themselves. In total, the case organizations had seven different districts and a total of 25 home care teams that participated in the study.

\section{Measures}

All variables used in the study are presented in Table 1. Outcome variables were job satisfaction, stress, psychological distress and quality of care. Job satisfaction was measured with one question ('In general, I am very satisfied with my job') and respondents were asked to evaluate this on a five-point Likert scale $(1$ - 'strongly agree' to 5 - 'strongly disagree') [43]. Stress was measured with one question: Do you currently feel stressed? (Stress means a situation when a person feels tense, restless, nervous or anxious, or is unable to sleep at night because his or her mind is troubled all the time) [44]. This was rated on a 5-point scale from 'not at all' to 'very much'. To measure staff members' psychological distress, a short version of the General Health Questionnaire (GHQ) was used [45]. Four items were selected: Have you recently lost a lot of sleep due to some worry? Have you recently been feeling unhappy and depressed? Have you recently felt constantly under strain? and Have you recently felt that you could not overcome your difficulties? The Cronbach's alpha value for the four items was .83. Lastly, quality of care (QoC) was initially a sum of eight variables with a Cronbach's alpha value of .84 . In order to improve the consistency of the scale, one variable was removed. After removal, the alpha value was .87. The respondents assessed their co-workers' 1) professional competence, 2) way of treating clients, 3) friendliness, 4) ability to answer clients' requests for assistance, 5) ability to consider clients' self-determination, 6) knowledge of issues related to the client, and 7) ability to consider the client's next of kin. Here the rating was on a five-point scale from excellent (1) to bad (5) [46].

The predictors used in the study were chosen based on the three most well-known theories related to employee well-being (the Job Strain model, Team Climate Inventory and the Procedural Justice model). Our aim was to explore the associations between the outcome variables and predictors related to these models by using all the predictors in the same model to detect the most significant predictors. The predictors were categorised under the theoretical models. The first category was organizational justice, including a predictor of relational justice [49], the second category was teamwork, which included participative safety, shared goals and idea implementation predictors from the Team Climate Inventory [50] and support for innovation from Innovativeness scale by de Jong and den Hartog [51]. The third category was based on the Demand and Control model $[10,11]$ including predictors of social support, skill discretion and autonomy at work, and three predictors that have been identified as stressors in home care and care work by earlier studies [7-9]: working alone, interruptions at work [47] and time pressure [48]. All measures used in the survey are free to use for research purposes and do not require any license payments.

\section{Data collection}

The contact details of the home care workers who worked in the participating districts and teams were provided for us. A postal survey was sent to all home care workers of the participating teams in the two case organizations $(N=179)$. The number of staff members per team varied from three to 16 . Teams were voluntarily able to take part in the project and to take a job satisfaction survey. The survey was aimed at permanent staff or substitutes who had worked in their current team for more than 6 months. The staff members were able to answer the survey in Finnish or Swedish (due to bilingualism of one municipality), and the response period was between April and May 2018. Reminders prompting participants to respond to the survey were sent twice: the first 3 weeks after the first survey round, and the second 3 weeks after the second survey round. Supervisors were asked to remind staff members to answer the survey.

\section{Statistical methods}

The survey data was analysed using analysis of covariance. First we used univariate analysis to analyse each predictor separately with each outcome variable to detect significant associations. Then analysis of covariance was performed with those predictors that were significantly associated with the outcome variables. Predictors with low association with the outcome variable were removed from the models stepwise, by first removing the one with the lowest association, then the second lowest and so on, until only the significant ones were left in the model. In total, this was performed for four separate models where job satisfaction, stress, psychological distress (GHQ) and quality of care were the outcome variables. Age and sex were adjusted for in all the covariance models. Significant associations for both univariate and multivariate associations are shown in 
Table 1 Outcome variables and predictors used in the study

\begin{tabular}{|c|c|c|c|c|c|}
\hline & Question & Scale & $\begin{array}{l}\text { Mean } \\
\text { (SD) }\end{array}$ & $\begin{array}{l}\text { Cronbach's } \\
\text { a }\end{array}$ & Reference \\
\hline \multicolumn{6}{|l|}{ Outcome variables } \\
\hline Job satisfaction & Generally speaking, I am very satisfied with my job & $\begin{array}{l}1 \text { 'fully disagree' - } 5 \\
\text { 'fully agree' }\end{array}$ & $\begin{array}{l}3.69 \\
(1.05)\end{array}$ & & [43] \\
\hline Stress & $\begin{array}{l}\text { Do you currently feel stressed? Stress means a } \\
\text { situation when a person feels tense, restless, } \\
\text { nervous, or anxious, or is unable to sleep at } \\
\text { night because his or her mind is troubled all } \\
\text { the time. }\end{array}$ & $\begin{array}{l}1 \text { 'not at all' - } \\
5 \text { 'very much' }\end{array}$ & $\begin{array}{l}2.70 \\
(1.10)\end{array}$ & & [44] \\
\hline Psychological distress & $\begin{array}{l}\text { Have you recently lost a lot of sleep over } \\
\text { worry?; Have you recently been feeling } \\
\text { unhappy and depressed?; Have you recently } \\
\text { felt constantly under strain?; Have you } \\
\text { recently felt you couldn't overcome your } \\
\text { difficulties? }\end{array}$ & $\begin{array}{l}1 \text { 'not at all' - } 4 \text { 'much } \\
\text { more than usually' }\end{array}$ & $2.14(.74)$ & .83 & {$[45]$} \\
\hline \multirow[t]{2}{*}{ Quality of care } & How would you assess your co-workers' ... & & & & \\
\hline & $\begin{array}{l}\text { 1) professional competence, 2) way of treating } \\
\text { clients, 3) friendliness, 4) ability to answer } \\
\text { clients' requests for assistance, 5) ability to } \\
\text { consider clients' self-determination, 6) } \\
\text { knowledge of issues related to the client and } \\
\text { 7) ability to consider the client's next of kin. }\end{array}$ & 1 'bad' - 5 'excellent' & $3.99(.49)$ & .87 & [46] \\
\hline
\end{tabular}

\section{Work stressors}

How often, during the past 6 months, have you felt disturbed, worried or strained due to ...

Working alone Lack of consultation possibilities and collegial help?

Interruptions Constant interruptions and that work cannot be performed uninterrupted?

Time pressure I do not have enough time for patients; I do not have enough time to perform work properly; I only have time for the necessary tasks

\section{Organizational justice}

Relational justice

My supervisor treats his/her employees with kindness and consideration; My supervisor treats his/her employees respectfully; My supervisor considers his/her employees' needs and listens to them.

\section{Job control}

Skill discretion

My work requires that I learn new skills

Autonomy

Social support

\section{Teamwork}

Participative safety

Shared goals
At my work, I can make a lot of independent decisions

When needed, I receive support from my 1 . co-workers, 2. supervisors.

We have a "we are in it together" attitude; We keep each other informed about work related issues; We feel understood and accepted by each other; There are real attempts to share information throughout the practice

Are you in agreement with the objectives set at you unit?; To what extent do you think your team's objectives are clearly understood by other members of the team?; To what extent do you think

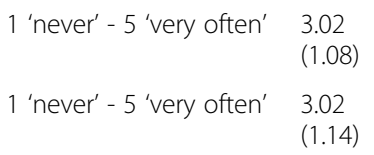

1 'never' - 5 'very often' $3.56(.95)$

1 'fully disagree' - 5 'fully 4.36 (.75) agree'

1 'fully disagree' - 5 'fully 3.75 (.83) agree'

1 'never' - 5 'always' 3.81 (.83) 
Table 1 Outcome variables and predictors used in the study (Continued)

\begin{tabular}{|c|c|c|c|c|c|}
\hline & Question & Scale & $\begin{array}{l}\text { Mean } \\
\text { (SD) }\end{array}$ & $\begin{array}{l}\text { Cronbach's } \\
\text { a }\end{array}$ & Reference \\
\hline & $\begin{array}{l}\text { your team's objectives can actually be achieved?; } \\
\text { How worthwhile do you think these objectives are } \\
\text { to your team? }\end{array}$ & & & & \\
\hline Idea implementation & $\begin{array}{l}\text { New initiatives and ideas are taken up and assessed; } \\
\text { At our work community, we can independently decide } \\
\text { upon the implementation of a new development idea; } \\
\text { At my work community, new thoughts and ideas are } \\
\text { taken into action efficiently; Initiatives and ideas often } \\
\text { lead to new practices, services and products in our } \\
\text { organization }\end{array}$ & $\begin{array}{l}1 \text { 'fully disagree' - } 5 \\
\text { 'fully agree' }\end{array}$ & $2.91(.78)$ & .81 & [50] \\
\hline $\begin{array}{l}\text { Support for } \\
\text { innovation }\end{array}$ & $\begin{array}{l}\text { Search for new ways of looking at problems; Time taken } \\
\text { to develop ideas; Cooperation in developing and } \\
\text { applying ideas }\end{array}$ & $\begin{array}{l}1 \text { 'fully disagree' - } 5 \\
\text { 'fully agree' }\end{array}$ & $3.13(.72)$ & .75 & [51] \\
\hline
\end{tabular}

Table 2. Statistical analyses were performed with SPSS version 25 .

\section{Semi-structured theme interviews}

Our material was gathered by conducting semistructured theme interviews. A semi-structured interview has predetermined themes, and they can be modified or additional themes and questions can be included depending on what is appropriate for a particular interview [52]. The use of semi-structured theme interviews were considered appropriate for the purposes of this study, because semi-structured theme interviews have been found to be suitable in situations where a study focuses on the meaning of particular phenomena to the participants and where individual perceptions of processes within a social unit are studied [52].

The themes of the interviews selected for this particular study included: 1. Job satisfaction, 2. Leadership and management, 3. Client work and client satisfaction, 4. Teamwork and its functioning, and 5. Trust. The themes were chosen to gain as comprehensive understanding of the case organizations' home care, and its functioning, as possible. Even though the themes were predetermined, it should be pointed out that these themes did not restrict the emergence of any other theme considered important by the interviewees. In other words, the structure of the interviews was not restricted to issues only emerging from the five themes. The interviewees were able to

Table 2 Results from the analysis of covariance showing both univariate and multivariate associations for each outcome variable

\begin{tabular}{|c|c|c|c|c|c|c|c|c|}
\hline & \multicolumn{2}{|c|}{ Model 1} & \multirow{2}{*}{\multicolumn{2}{|c|}{$\frac{\text { Model } 2}{\text { Stress }}$}} & \multirow{2}{*}{\multicolumn{2}{|c|}{$\begin{array}{l}\text { Model } 3 \\
\text { Psychological distress }\end{array}$}} & \multirow{2}{*}{\multicolumn{2}{|c|}{$\frac{\text { Model } 4}{\text { Quality of Care }}$}} \\
\hline & \multicolumn{2}{|c|}{ Job satisfaction } & & & & & & \\
\hline & $\begin{array}{l}\text { Univariate } \\
(\mathrm{F}, \mathrm{p})\end{array}$ & $\begin{array}{l}\text { Multivariate } \\
(\mathrm{F}, \mathrm{p})\end{array}$ & $\begin{array}{l}\text { Univariate } \\
(\mathrm{F}, \mathrm{p})\end{array}$ & $\begin{array}{l}\text { Multivariate } \\
(\mathrm{F}, \mathrm{p})\end{array}$ & $\begin{array}{l}\text { Univariate } \\
(\mathrm{F}, \mathrm{p})\end{array}$ & $\begin{array}{l}\text { Multivariate } \\
(\mathrm{F}, \mathrm{p})\end{array}$ & $\begin{array}{l}\text { Univariate } \\
(\mathrm{F}, \mathrm{p})\end{array}$ & $\begin{array}{l}\text { Multivariate } \\
(\mathrm{F}, \mathrm{p})\end{array}$ \\
\hline Working alone & $3.28, *$ & 0.02 , ns & $3.41, *$ & $0.11, \mathrm{~ns}$ & $5.11, * *$ & $5.64, *$ & 1.16 , ns & $\ldots$ \\
\hline Interruptions & $6.66,{ }^{* *}$ & $15.01, * *$ & $6.76,{ }^{* *}$ & $7.10, * *$ & $6.12, * *$ & $3.66, \mathrm{~ns}$ & $2.64{ }^{*}$ & $1.88, \mathrm{~ns}$ \\
\hline Time pressure & $3.29, * *$ & 2.16 , ns & $4.10, * *$ & $6.69, *$ & $4.36, * *$ & $9.84, * *$ & $1.48, \mathrm{~ns}$ & $\ldots$ \\
\hline Relational justice & $3.13,^{* *}$ & 2.97, ns & $2.50, * *$ & $1.03, \mathrm{~ns}$ & $3.63, * *$ & $5.29, *$ & $1.38, \mathrm{~ns}$ & $\ldots$ \\
\hline Skill discretion & $0.33, \mathrm{~ns}$ & $\ldots$ & $0.81, \mathrm{~ns}$ & $\ldots$ & $0.25, \mathrm{~ns}$ & $\ldots$ & $1.49, \mathrm{~ns}$ & $\ldots$ \\
\hline Autonomy & $2.58, *$ & $10.01, * *$ & $1.46, \mathrm{~ns}$ & $\ldots$ & $2.97, *$ & $0.94, \mathrm{~ns}$ & $1.31, \mathrm{~ns}$ & $\ldots$ \\
\hline $\begin{array}{l}\text { Participative } \\
\text { safety }\end{array}$ & $2.62,{ }^{* *}$ & 3.42 , ns & $1.30, \mathrm{~ns}$ & $\ldots$ & $1.18, \mathrm{~ns}$ & $\ldots$ & $5.22, * *$ & $21.35, * *$ \\
\hline Shared goals & $2.75, * *$ & $1.71, \mathrm{~ns}$ & $1.63, \mathrm{~ns}$ & $\ldots$ & $0.73, \mathrm{~ns}$ & $\ldots$ & $4.49, * *$ & $4.39, *$ \\
\hline Social support & $6.27, * *$ & 0.47 , ns & $3.70, * *$ & $0.20, \mathrm{~ns}$ & $4.18, * *$ & $0.20, \mathrm{~ns}$ & $5.83, * *$ & $0.34, \mathrm{~ns}$ \\
\hline $\begin{array}{l}\text { Support for } \\
\text { innovation }\end{array}$ & $3.38, * *$ & $0.08, \mathrm{~ns}$ & $2.05, *$ & $0.11, \mathrm{~ns}$ & $2.38, * *$ & $1.15, \mathrm{~ns}$ & $4.47, * *$ & $0.47, \mathrm{~ns}$ \\
\hline Idea & $3.07, * *$ & $10.97, * *$ & $2.19, *$ & $7.08, * *$ & $1.48, \mathrm{~ns}$ & $\ldots$ & $6.25, * *$ & $16.72, * *$ \\
\hline & & Adjusted $R^{2} .34$ & & Adjusted $R^{2} .31$ & & Adjusted $R^{2} .29$ & & Adjusted $R^{2} .46$ \\
\hline
\end{tabular}

${ }^{*} p<0.05$

${ }^{* *} p<0.01$

... Not tested in the final model due to non-significant univariate association 
freely discuss any topic they found relevant in relation to their work.

We interviewed 15 employees in 2018. Interviews lasted from 45 to $60 \mathrm{~min}$ and they were tape-recorded with permission from the interviewees and transcribed verbatim by a professional service firm. Interviewees were practical nurses $(n=14)$ with one registered nurse. All the participants were female. The anonymity of the participants was secured so that no individual is identifiable from the analysis. The interviews were carried out in Finnish, which is the interviewees' native language, and then translated into English when writing the research report.

\section{Analysis of data}

Since our focus was on exploring the perceptions of home care workers related to their work, we decided to use interpretive and inductive research methods. In this study, a Grounded Theory approach was chosen because [53] it has been argued to be especially suitable in research areas where there is not enough knowledge or to which there is a need for new points of view [54].

In this paper we have adopted a Grounded Theorybased method, introduced by Gioia et al. [55] for the identification of essential conceptual categories. This method, used particularly in organizational studies, comprises first and second order analyses. The first order analysis captures salient findings from the interviews, with an attempt to adhere faithfully to informant terms [55]. This process has similarities with the process of open coding, as described by Strauss and Corbin [53]. In this step, we captured all portions from the interview that seemed important to the interviewees, using words that the interviewees had originally used themselves. In the second order analysis the focus of analysis shifts to condensing the identified first order concepts into a more manageable number. This is first done by seeking similarities and differences among the many categories (similar to Strauss and Corbin's [53] notion of axial coding) and then asking whether the emerging themes suggest concepts that might help us describe and explain the phenomena we are observing [55]. Once a workable set of themes and concepts is in hand (and the culmination of the theme and concept development process leads to what Glaser and Strauss [56] termed 'theoretical saturation'), we distilled the emergent second order themes further into second order 'aggregate dimensions', as suggested by Gioia and his colleagues [55].

Even though our qualitative analysis has been inductive, allowing any kind of concept or aggregate dimension to emerge, we have made minor adjustments to the wording of some of the second order themes and aggregate dimensions at the end of analysis. The purpose of these adjustments has been to improve the opportunities to compare qualitative and quantitative research results. Although the aggregate dimensions that emerged in this analysis resulted in being notably similar with the outcome variables of the quantitative analysis, the second order concepts and aggregate dimensions have emerged without forcing the results beforehand with predefined codes. Our qualitative analysis has been inductive rather than deductive by nature.

\section{Results \\ Survey \\ Sample characteristics}

The total number of participants was 121 and the response rate was $67 \%$. Thirteen people responded to the survey in Swedish and 108 in Finnish. The mean age of the participants was 40.6 years, ranging from 19 to 65 years. Only two of the participants were male. The participants were mainly practical nurses $(N=104,86 \%)$, and registered nurses comprised $12 \%$ of the sample. Only one participant reported being in a managerial position. The educational background of the respondents was mainly (81\%) vocational training (licensed practical nurse or similar), and $12 \%$ had a degree from college or a university of applied sciences.

\section{Analyses of covariance}

The results from the univariate and covariance analyses are presented in Table 2 and Fig. 1. Analysis of covariance showed that interruptions, autonomy and idea implementation remained significant when all the variables were tested in the same model with job satisfaction (Table 2, model 1). Therefore, the predictors from the Demand-Control model were partly seen to explain job satisfaction as well as one predictor of the teamwork factors. With regard to stress, again the predictors from the Demand-Control model (interruptions at work and time pressure) and one teamwork factor (idea implementation) were associated with higher stress in multivariate analysis (model 2). The following predictors were associated with psychological distress: working alone and time pressure from the Demand-Control model and relational justice from the Organizational Justice model (model 3). Lastly, participative safety, shared goals and idea implementation of the Teamwork predictors were related to quality of care (model 4). Adjusted R squared values varied from .29 to .46 in the final models. These values could be considered to explain the variation in the outcome variables fairly well.

\section{Theme interviews}

As a result of following the Gioia methodology [55], we formed a graphical data structure showing how the analysis progressed from the data to the themes and aggregate dimensions (Fig. 2). This provides the reader with 


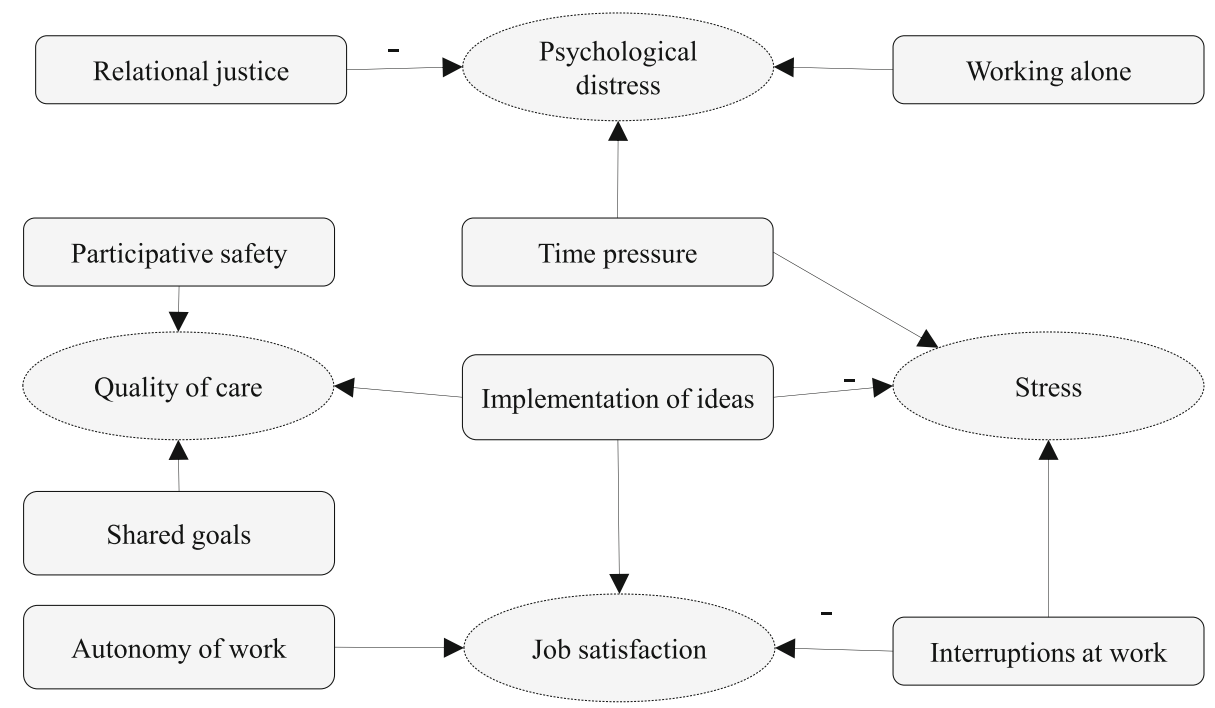

Fig. 1 Associations from the covariance analyses models. Outcome variables are illustrated with a dashed line circle and predictors with squares.

an opportunity to look at the grounded theory model and see how the essential concepts, themes and/or dimensions contained in the data structure were formed and how they are related to each other.

Our analysis revealed that although home care workers liked their work, current work processes and management styles seemed to lower their work satisfaction and increase stress. Home care workers felt that they were just pawns at the bottom of the hierarchy, being largely unable to influence the way work is planned. These feelings seem to have lowered home care worker's job satisfaction. The staff members also felt that the way work was organized did not adequately help them to accomplish their objectives. As some examples, the desire to schedule work efficiently in a centralised manner seemed to have created problems on a practical level, largely because it is not possible for resource planning systems to know all the subtle details related to the work to be done. As a result, staff members felt that they were always in a hurry, spending too much time driving from one place to another and spending too little time with the clients.

The current situation in home care seems to make staff members strained and exhausted. This has led many of them to consider whether they had the strength to continue if their situation did not improve. Exhaustion seemed to have increased the number of periods of sick leave, which has increased the workload for those still at work. Furthermore, home care as a workplace has started to gain a bad reputation, which has made it more difficult to recruit staff.

Home care workers felt that there is just not enough time to conduct their work the way they wanted to. Another problem that appeared to bother both staff members and clients was that clients were rarely seen by the same carer. This would suggest that there is an unarticulated assumption believing that it is relatively irrelevant which carer is caring for the client. The conducted interviews suggest that such an assumption may be false. Several carers highlighted the benefits of knowing the clients deeply and the problems with using substitute carers. Some of the home care workers have also felt that, due to the stressful and exhausting work conditions, their ability to collaborate has started to deteriorate. These observations seem to have led to lower quality of care.

\section{Discussion}

This study aimed to explore factors that are associated with Finnish home care workers' well-being and perceived quality of care using three of the most wellknown theoretical models related to employee wellbeing, teamwork and organizational justice. Furthermore, we wanted to understand how staff members perceive their work and other underlying factors that could disturb and stress the staff members and could be the potential causes of the stressors.

Previous studies have revealed problems among home care personnel with job characteristics $[6,7]$ and the results from our study support these findings. Our results highlight several factors that are shown to negatively influence home care workers' well-being.

Both qualitative and quantitative analyses show similarities in terms of stress factors. The survey showed that time pressure was associated with higher psychological distress and stress, whereas the interviews revealed that there are currently too few home care workers, which has caused exhaustion. In an attempt to deal with this 


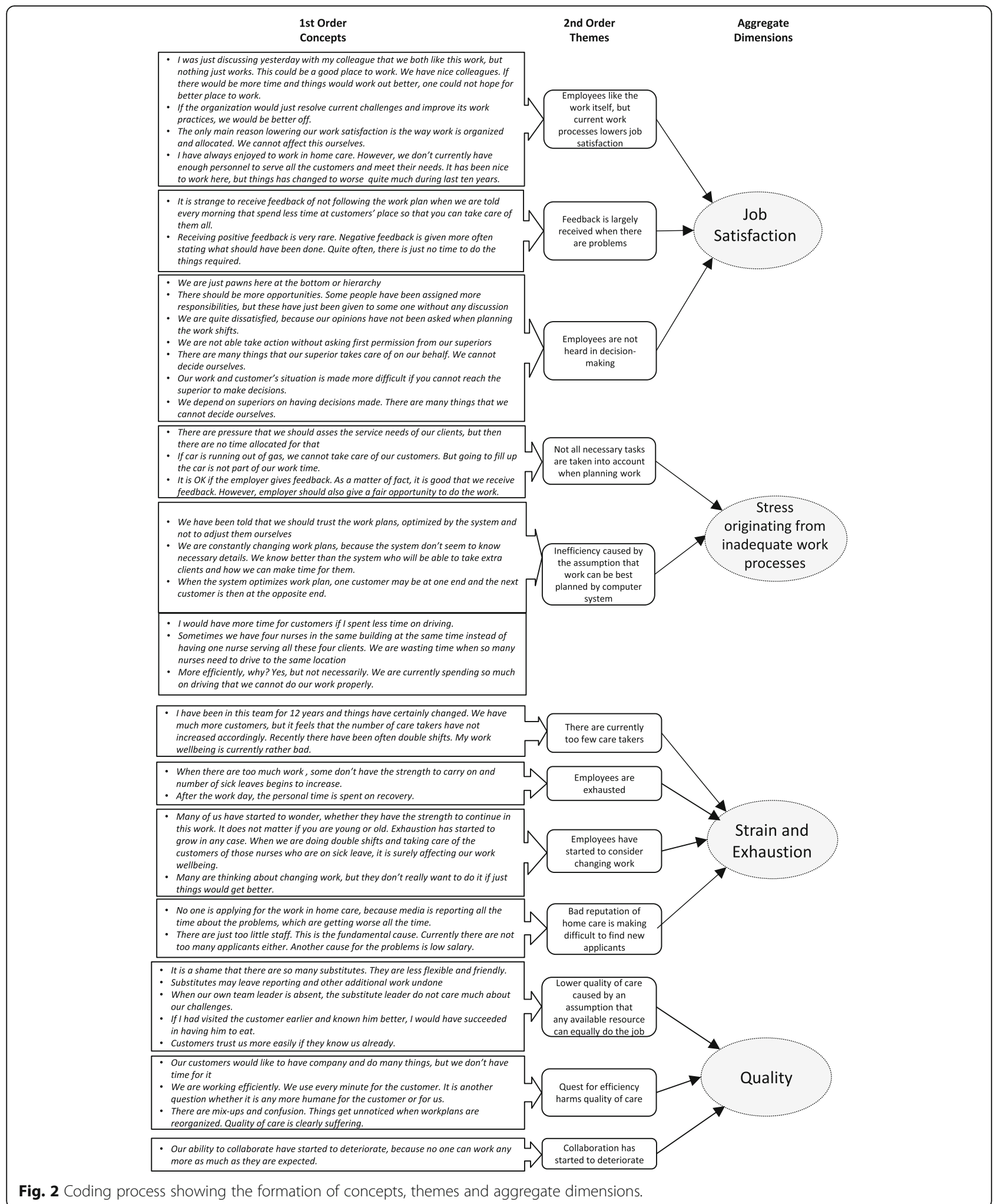

situation, the management teams of home care organizations seem to have often tried to optimise the use of existing staff members. Unfortunately, planned work processes have often turned out to be less than ideal on a practical level. The interviews revealed that problems with following processes and the inability to sufficiently 
influence the way work is conducted have increased home care workers' stress. This is in line with the quantitative finding indicating an increase in stress when the implementation of own ideas is not supported. The results, which suggest that organizational justice and working alone are related to distress, are also well in line with earlier results $[10,20]$. What is noteworthy is that autonomy of staff members, which is an important part of the demand-control model, was not related to psychological distress or experienced stress. This may be due to the characteristics of home care work, where work is highly independent. Autonomy at work was, however, related to job satisfaction.

Regarding job satisfaction, similarities with both qualitative and quantitative analysis were also found. Less autonomy at work and less idea implementation were shown to negatively influence job satisfaction, whereas the staff members stated in the interviews that they are not able to take action on their own and that there is a lack of opportunities to make decisions. The association between decision latitude and job satisfaction among nurses is widely known from the previous literature [57]. In the univariate analyses, relational justice was associated with job satisfaction but after adding other variables to the model, it lost its significance. In the qualitative analyses, management practices came up as home care workers stated being dissatisfied with their supervisors who did not listen to staff when making decisions. It is essential to enhance relational justice at workplaces, since it can be an important predictor of poorer selfrated health and sickness absence [18]. In particular, when aiming to increase self-organizing team practices, the role of management should be supportive rather than 'micromanaging'. These findings could be connected to the implementation of ideas as well. In quantitative analyses, idea implementation was associated with job satisfaction, stress and quality of care. A similar conclusion seemed to arise from the interview analyses where employees' experiences of not being heard in the decision-making process was linked to a decrease in job satisfaction. Moreover, one factor that might explain the dissatisfaction related to management in the present study could be that management practices varied across home care teams. Some supervisors were too controlling and the staff members were not able to take actions on their own, whereas other supervisors were absent and the staff members were not able to reach them. The findings suggest that job satisfaction could be increased by allowing home care workers to influence their job and increasing their ability to manage their working days. Autonomy of home care work is presumably one of the appealing characteristics of the job. A study conducted in Sweden also indicated that nurses working in community care appreciated the independence of their work and the ability to use their knowledge and skills [58]. However, due to current issues in Finnish home care, this appeal of autonomy at the employee level might no longer be true and further, problems with recruitment also arose from the findings of our study. Therefore, increasing the autonomy of home care teams could be one possible solution when aiming to attract more staff members to home care, prevent turnover and increase employee well-being.

Interruptions were also one of the stressors that was detected to be negatively associated with job satisfaction in the quantitative analyses. Interruptions can be a great source of frustration and increase the chance of errors [59]. Similar to the findings by Wilkes, et al. [60], our study identified an association between interruptions and stress. Interruptions have also been found to be a cause of other negative outcomes such as cognitive exhaustion [60] and a risk for patient safety [61]. Even though interruptions were strongly associated with stress and job satisfaction, the staff members did not highlight them significantly in the interviews. Still, their influence should not be neglected in home care work where work places and situations change frequently and care staff mainly work independently without other people to supervise or 'double check' their work.

Despite all the stressors arising from the results, there were some encouraging and positive aspects as well. The survey results showed that participative safety was associated with better quality of care and in the interviews the participants highlighted that they fully trusted their colleagues. This needs to be considered important, since trust can have a positive influence on employee wellbeing and job satisfaction [62]. Trust, however, was not covered in the survey and therefore we cannot draw very robust conclusions as to what extent it had an impact on the employee well-being or care quality. Moreover, home care workers stated in the interviews that they liked their work and based on their views the problems seemed to be more related to the processes and ways of organizing the work, rather than to the care work itself. Based on this finding it would be important to modify the work processes according to the suggestions from the staff members, for instance by allowing them to implement their ideas in improved practices. This could further increase their experience related to fair management, which could then lead to higher job satisfaction or less sickness absence [18].

The findings from the quantitative analyses regarding quality of care seemed to support the findings from the interviews to some extent; variables related to teamwork were important predictors in the univariate analyses and in the final model, participative safety, shared goals and idea implementation still remained significant. The relationship between the factors of teamwork and quality of 
care is an interesting finding, since there is very limited evidence of the relationship between team climate and quality of care $[29,30]$. There is, however, evidence that team climate is associated with team effectiveness [63]. In the present study, deterioration in collaboration between home care workers seems to have led to a decrease in care quality. It is interesting that in our study, factors explaining the quality of care were all related to teamwork, whereas earlier findings from hospitals and institutional care of older people are more related to stress and autonomy of staff members [23]. However, in the Magnet hospital study, both flat organization and decision-making authority at the work unit level were also highlighted [25].

The results from our study could be interpreted in a way that using self-organizing teams as a development method could have potential in Finnish home care services. Staff members stated that they were better at planning their daily work schedules than the planning system they used at work. The interviews showed that the team members felt they had very little opportunity to make decisions, and they had to ask permission from supervisors, even for small things. By giving staff the opportunity to put their ideas into practice, there could be a potential effect on well-being and even better care quality. The importance of idea implementation could also indicate that staff, in general, want to be able to and are capable of participating in the development of their job. Based on the findings of our study, giving staff a chance to implement better practices at work could have several benefits in terms of their well-being. It is worth noting that home care workers themselves know their work best.

\section{Limitations}

There were several limitations to this study. First of all, our sample size was very small. Furthermore, no other professional groups working in home care (such as physiotherapists or occupational therapists) were included in this study; therefore, this study provided only the views of practical nurses and registered nurses. Due to issues with data quantity, a mixed-methods approach was used in the study in order to gain richer data. Secondly, supervisors in the participating teams might have been aware of those who had not responded to the survey in the first round since they were in charge of delivering the surveys at the work units to those individuals who did not respond. This could have led to staff feeling compelled to respond to the survey, even if participation was on a voluntary basis. Thirdly, no causal relationship can be drawn from the results of the study, since a cross-sectional design was used. Therefore, no thorough conclusions can be made from the results since a crosssectional study design can only provide a snapshot of a current situation and cannot take into account all factors that can influence the findings. Fourthly, the themes of the interviews could have been selected more according to the questions in the survey. For example, trust was not covered in the questionnaire even though it could have provided more robust conclusions related to home care staff members' well-being or job satisfaction when combined with the qualitative analyses. However, the themes of the interviews were only loosely predetermined and similar topics arose from the analyses of the interview data as from results of the covariance analyses.

\section{Conclusions}

Current working conditions and work practices in Finnish home care are considered stressful. For instance, staff members suffer from time pressure and interruptions. In addition, what transpired from the interviews was that high levels of absence of staff members led to strain and exhaustion among other staff members. In addition, the results showed that having more autonomy at work, i.e. being able to influence one's job, was associated with job satisfaction. The survey results further showed that team climate and innovativeness of teams were related to quality of care. The results of this study could be interpreted to mean that implementing selforganizing team practices might be a possible development method to improve the situation of home care workers. If staff members could influence their work, this could have a positive impact on their well-being, through improved job satisfaction, for instance. On a broader scale, implementing self-organizing team practices could potentially increase the attractiveness of work in home care and prevent turnover of home care staff.

\section{Abbreviations}

GHQ: General health questionnaire; QoC: Quality of care

\section{Acknowledgements}

The authors would like to thank the home care staff who participated in the study.

\section{Authors' contributions}

SR and TS designed the study. SR drafted the manuscript and performed the statistical analysis. SJ performed the qualitative analysis. All authors revised the manuscript. Further, all authors read and approved the final manuscript.

\section{Funding}

This study was funded by the Finnish Work Environment Fund, project number 117138

\section{Availability of data and materials}

Both quantitative and qualitative datasets used and/or analysed during the current study are available from the corresponding author on reasonable request. Note that the transcribed qualitative interview data is in Finnish.

\section{Ethics approval and consent to participate}

The ethical approval was obtained from the Ethics Committee of the Finnish Institute for Health and Welfare. When the survey was sent to the

participants, they first had to fill in a separate consent form and return it with the survey. If a participant did not complete a consent form, they were excluded from the study. The interview participants were asked to provide 
their consent to participate before the interview, and were required to fill out a consent form.

\section{Consent for publication}

Not applicable.

\section{Competing interests}

The authors declare that they have no competing interests.

\section{Author details}

${ }^{1}$ Finnish Institute for Health and Welfare, P.O. Box 30, 00271 Helsinki, Finland. ${ }^{2}$ South-Eastern Finland University of Applied Sciences, P.O. Box 68, 50101 Mikkeli, Finland.

\section{Received: 17 January 2020 Accepted: 13 September 2020}

Published online: 23 September 2020

\section{References}

1. Ministry of Social Affairs and Health: Sosiaali- ja terveydenhuollon kansallinen kehittämisohjelma (THE KASTE PROGRAMME) 2012-2015. 2012, http://urn.fi/URN:ISBN:978-952-00-3358-3.

2. Genet N, Boerma WGW, Kringos DS, Bouman A, Francke AL, Fagerström C Melchiorre MG, Greco C, Devillé W. Home care in Europe: a systematic literature review. BMC Health Serv Res. 2011:11(1):207.

3. Mielikäinen $L$, Kuronen R: Kotihoito ja sosiaalihuollon laitos- ja asumispalvelut 2018 [Home care and institutional and housing services of social care in 2018]. 2019, Finnish Institute for Health and Welfare http://urn. fi/URN:NBN:fi-fe2019111337862 Appendix tables available in English\&nbsp;

4. Ministry of Social Affairs and Health: Reform of home care for older people and informal care for all age groups 2016-2018. Results and operational frameworks. 2019, http://urn.fi/URN:ISBN:978-952-00-4060-4 In Finnish, abstract in English.

5. Alastalo H, Vainio S, Kehusmaa S: Kotihoidon asiakasmäärät kasvussa, henkilöstön määrän kasvu ei kaikissa maakunnissa seuraa perässä (Number of home care clients is increasing but the number of personnel in not increasing accordingly in all counties). 2017, National Institute for Health and Welfare http://urn.fi/URN:ISBN:978-952- 302-899-9 [In Finnish].

6. Kröger T, Van Aerschot L, Puthenparambil JM. Hoivatyö muutoksessa: suomalainen vanhustyö pohjoismaisessa vertailussa [In Finnish]. 2018,University of Jyväskylä, YFI Publications. https://jyx.jyu.fi/handle/123456 $789 / 57183$.

7. Vehko $T$, Josefsson $K$, Lehtoaro S, Sinervo T: Vanhuspalveluiden henkilöstö ja työn tuloksellisuus rakennemuutoksessa [Personnel and work efficiency in services for older people during structural changes]. 2018, National Institute for Health and Welfare. Report 16/2018. 83 pages. http://urn.fi/URN:ISBN: 978-952-343-241-3 Abstract in English.

8. Grundgeiger T, Sanderson P. Interruptions in healthcare: theoretical views. Int J Med Inform. 2008:78(5):293-307.

9. Swedberg L, Hammar Chiriac E, Törnkvist L, Hylander I. From risky to safer home care: health care assistants striving to overcome a lack of training, supervision, and support. Int J Qual Stud Health Well Being. 2013;8(1):20758.

10. Karasek R, Theorell T. Healthy work. Stress, productivity, and reconstruction of working life. New York: Basic books; 1990.

11. Karasek RA. Job demands, job decision latitude, and mental strain: implications for job redesign. Adm Sci Q. 1979;24(2):285-308.

12. Han K, Trinkoff AM, Gurses AP. Work-related factors, job satisfaction and intent to leave the current job among United States nurses. J Clin Nurs. 2015;24(21-22):3224-32.

13. Anderson NR, West MA. Measuring climate for work group innovation: development and validation of the team climate inventory. J Organ Behav. 1998;19(3):235-58.

14. Manser T. Teamwork and patient safety in dynamic domains of healthcare: a review of the literature. Acta Anaesthesiol Scand. 2009:53(2):143-51.

15. Elovainio M, Steen N, Presseau J, Francis J, Hrisos S, Hawthorne G, Johnston M, Stamp E, Hunter M, Grimshaw JM, Eccles MP. Is organizational justice associated with clinical performance in the care for patients with diabetes in primary care? Evidence from the improving quality of care in diabetes study. Fam Pract. 2013;30(1):31-9.

16. Schwendimann R, Dhaini S, Ausserhofer D, Engberg S, Zúñiga F. Factors associated with high job satisfaction among care workers in Swiss nursing homes - a cross sectional survey study. BMC Nurs. 2016;15(1):37.
17. King EB, Chermont K, West M, Dawson JF, Hebl MR. How innovation can alleviate negative consequences of demanding work contexts: the influence of climate for innovation on organizational outcomes. J Occup Organ Psychol. 2007:80(4):631-45.

18. Elovainio M, Kivimaki M, Vahtera J. Organizational justice: evidence of a new psychosocial predictor of health. Am J Public Health. 2002;92(1):105-8.

19. Sulander J, Sinervo T, Elovainio M, Heponiemi T, Helkama K, Aalto A. Does organizational justice modify the association between job involvement and retirement intentions of nurses in Finland? Res Nurs Health. 2016;39(5):364-74.

20. Elovainio M, Heponiemi T, Sinervo T, Magnavita N. Organizational justice and health; review of evidence. G Ital Med Lav Ergon. 2010;32(3 Suppl B):5.

21. Elovainio $M$, Kivimäki $M$, Eccles $M$, Sinervo T. Team climate and procedural justice as predictors of occupational strain. J Appl Soc Psychol. 2002;32(2): 359-72.

22. Lehtoaro $\mathrm{S}$, Josefsson $\mathrm{K}$, Sinervo T. Professionals' self-rated quality of care and its relation to competence, national guidelines and policies - a crosssectional study among Finnish elderly care workers. BMC Health Serv Res. 2018;18(1):896.

23. Pekkarinen $L$, Sinervo $T$, Elovainio M, Noro A, Finne-Soveri H. Drug use and pressure ulcers in long-term care units: do nurse time pressure and unfair management increase the prevalence? J Clin Nurs. 2008;22:3067.

24. Pekkarinen L, Sinervo T, Perala M, Elovainio M. Work stressors and the quality of life in long-term care units. Gerontologist. 2004;5:633.

25. McClure ML, Muriel AP, Margaret D. Sovie, M. S., Wandelt MA: Magnet Hospitals Attraction and Retention of Professional Nurses (The Original Study). 1983.

26. Aiken LH, Buchan J, Ball J, Rafferty AM. Transformative impact of magnet designation: England case study. J Clin Nurs. 2008;17(24):3330-7.

27. Flynn L, Liang Y, Dickson GL, Aiken LH. Effects of nursing practice environments on quality outcomes in nursing homes. J Am Geriatr Soc. 2010:58(12):2401-6.

28. Aiken LH, Sloane DM, Clarke S, Poghosyan L, Cho E, You L, Finlayson M, Kanai-Pak M, Aungsuroch Y. Importance of work environments on hospital outcomes in nine countries. Int J Qual Health Care. 2011;23(4):357-64.

29. Bower P, Campbell S, Bojke C, Sibbald B. Team structure, team climate and the quality of care in primary care: an observational study. Qual Saf Health Care. 2003;12(4):273-9.

30. Mundt MP, Agneessens F, Tuan W, Zakletskaia LI, Kamnetz SA, Gilchrist VJ. Primary care team communication networks, team climate, quality of care, and medical costs for patients with diabetes: a cross-sectional study. Int J Nurs Stud. 2016;58:1-11.

31. Monsen KA, de Blok J. Buurtzorg: nurse-led community care. Creat Nurs. 2013;19(3):122-7.

32. Maurits EEM, de Veer AJE, Groenewegen PP, Francke AL. Home-care nursing staff in self-directed teams are more satisfied with their job and feel they have more autonomy over patient care: a nationwide survey. J Adv Nurs. 2017;73(10):2430-40

33. Weerheim W, Van Rossum L, Ten Have WD. Successful implementation of self-managing teams. Leadersh Health Serv. 2019;32(1):113-28.

34. Magpili NC, Pazos P. Self-managing team performance: a systematic review of multilevel input factors. Small Group Res. 2018;49(1):3-33.

35. Social Welfare Act 1301/2014. 2014, http://finlex.fi/en/laki/kaannokset/1982/ en19820710_20140491.pdf (Unofficial translation).

36. Health Care Act 1326/2010. 2010, https://www.finlex.fi/fi/laki/kaannokset/201 0/en20101326_20131293.pdf (Unofficial translation).

37. Kröger T, Van Aerschot L, Mathew Puthenparambi J. Ikääntyneiden hoivaköyhyys [Care poverty among older people]. Yhteiskuntapolitiikka. 2019:84(2):124-34.

38. Finnish National Board of Education: Vocational qualification in social and health care, practical nurse 2010. 2011, Finnish National Board of Education Publications 2011:21 ISBN 978-952-13-4873-0 (pdf).

39. Noro A, Alastalo H, Finne-Soveri H, Mäkelä M: Kotihoidon toimintamallit ja henkilöstö vuonna 2014 -Vanhuspalvelulain toimeenpanon seurantatutkimus [Work methods and personnel in home care in 2014 - a follow-up study of the implementation of the Act on the Care Services for Older Persons]. 2015, Tutkimuksesta tiiviisti 2, Helmikuu 2015. Terveyden ja hyvinvoinnin laitos, Helsinki http://urn.fi/URN:ISBN:978-952-302-440-3 In Finnish.

40. Szebehely M, Meagher G. Nordic eldercare - weak universalism becoming weaker? J Eur Soc Policy. 2018;28(3):294-308. 
41. Matveinen P: Terveydenhuollon menot ja rahoitus 2017 [Health expenditure and financing in 2017]. 2019, National Institute for Health and Welfare http://urn.fi/URN:NBN:fi-fe2019051415433 In Finnish.

42. Sale J, Lohfeld L, Brazil K. Revisiting the quantitative-qualitative debate: implications for mixed-methods research. Qual Quant. 2002;36(1):43-53.

43. Hackman JR, Oldham GR. Development of the job diagnostic survey. J Appl Psychol. 1975;60(2):159-70

44. Elo A, Leppänen A, Jahkola A. Validity of a single-item measure of stress symptoms. Scand J Work Environ Health. 2003;29(6):444-51.

45. Goldberg LR. Some recent trends in personality assessment. J Pers Assess. 1972;36(6):547.

46. Vaarama M, Kainulainen S, Perälä M, Sinervo T: Vanhusten laitoshoidon tila : Voimavarat, henkilöstön hyvinvointi ja hoidon laatu [State of institutionalized care for the elderly: Resources, personnel well-being and quality of care]. 1999, Stakes : 46/1999.

47. Elovainio M, Sinervo T: Vanhainkotien kehittämisen seurantatutkimus . 1994, STAKES Tutkimuksia 44.

48. Harris PE. The nurse stress index. Work Stress. 1989;3(4):335-46.

49. Elovainio M, Heponiemi T, Kuusio H, Sinervo T, Hintsa T, Aalto A. Developing a short measure of organizational justice: a multisample health professionals study. J Occup Environ Med. 2010;52(11):1068-74.

50. Kivimaki M, Elovainio M: A short version of the team climate inventory: development and psychometric properties. J Occup Organ Psychol 1999, 72(2):241-246.Wiley Online Library https://doi.org/https://doi.org/10.1348/ 096317999166644.

51. de Jong J, den Hartog D. Measuring innovative work behaviour. Creat Innov Manag. 2010;19(1):23-36.

52. Robson C. Real World Research: A Resource for Social Scientists and Practitioner-Researchers. 2nd ed. Oxford: Blackwell; 2002.

53. Strauss A, Corbin JM. Basics of qualitative research: grounded theory procedures and techniques. Newbury Park: Sage Publications, Inc; 1990.

54. Chenitz WC, Swanson JM. From practice to grounded theory. California: Addison-Wesley Publishing Company; 1986.

55. Gioia DA, Corley KG, Hamilton AL. Seeking qualitative rigor in inductive research. Organ Res Methods. 2013;16(1):15-31.

56. Glaser BG, Strauss AL. The discovery of grounded theory: strategies for qualitative research. Chicago: Aldine; 1967.

57. McVicar A. Scoping the common antecedents of job stress and job satisfaction for nurses (2000-2013) using the job demands-resources model of stress. J Nurs Manag. 2016;24(2):E112-36.

58. Josefsson K, Åling J, Östin B. What implies the good work for registered nurses in municipal elderly Care in Sweden? Clin Nurs Res. 2011;20(3):292309.

59. Tucker AL, Spear SJ. Operational failures and interruptions in hospital nursing. Health Serv Res. 2006;41(3p1):643-62.

60. Wilkes SM, Barber LK, Rogers AP. Development and validation of the workplace interruptions measure. Stress Health J Int Soc Invest Stress. 2018; 34(1):102-14.

61. Campbell G, Arfanis K, Smith AF. Distraction and interruption in anaesthetic practice. Br J Anaesth. 2012;109(5):707-15.

62. Meng J, Berger BK. The impact of organizational culture and leadership performance on PR professionals' job satisfaction: testing the joint mediating effects of engagement and trust. Public Relat Rev. 2019;45(1):64-75.

63. Strating MMH, Nieboer AP. Psychometric test of the team climate inventoryshort version investigated in Dutch quality improvement teams. BMC Health Serv Res. 2009;9(1):126

\section{Publisher's Note}

Springer Nature remains neutral with regard to jurisdictional claims in published maps and institutional affiliations.

Ready to submit your research? Choose BMC and benefit from:
- fast, convenient online submission
- thorough peer review by experienced researchers in your field
- rapid publication on acceptance
- support for research data, including large and complex data types
- gold Open Access which fosters wider collaboration and increased citations
- maximum visibility for your research: over 100M website views per year
At BMC, research is always in progress.
Learn more biomedcentral.com/submissions

